\title{
Negócio Jurídico Processual sobre a Multa Coercitiva
}

\author{
Procedural Contract about the Coercitive Fine
}

\author{
Vitor Henrique Melo de Albuquerque' \\ Felipe Costa Laurindo do Nascimento ${ }^{2}$ \\ ${ }^{1,2}$ Universidade Federal de Alagoas - UFAL, Brasil
}

\begin{abstract}
Resumo
O negócio jurídico processual e a efetividade dos provimentos judiciais são temas marcantes na sistemática processual brasileira. Sobre o primeiro, o respeito ao autorregramento da vontade e a cláusula geral de atipicidade negocial perfazem a noção idealizada de processo desenvolvido em favor dos interessados e flexível aos seus interesses particulares. A respeito do segundo, técnicas processuais foram desenvolvidas e delineadas no sentido de corresponder às necessidades do direito material. Em meio a esse cenário, encontra-se a multa coercitiva, aqui também denominada astreinte. Considerando a imperatividade estatal, as premissas autorizadoras dos negócios jurídicos processuais, a disponibilidade da execução e a natureza jurídica da astreinte, analisar-se-á a possibilidade de negociação em torno dos aspectos que envolvem a multa coercitiva.

Palavras-chave: negócio jurídico processual; autorregramento da vontade; multa coercitiva
\end{abstract}

\begin{abstract}
The procedural contract and the effectiveness of judicial procedures are outstanding themes in the Brazilian procedural system. Regarding the first, respect for the parties' case management powers and the general clause of atypicality make up the idealized notion of a process developed in favor of interested parties and flexible to their particular interests. Regarding the second, procedural techniques were developed and outlined in order to meet the needs of material law. In the midst of this scenario, there is a coercive fine, here also called astreinte. Considering the state imperativity, the authorizing premises of procedural contracts, the availability of execution, and the legal nature of the astreinte, the possibility of negotiation around the aspects involving the coercive fine will be analyzed.
\end{abstract}

Keywords: procedural contract; parties management powers; coercive fine

\section{Introdução}

A visão da excessiva formalidade como garantidora da segurança jurídica e do melhor interesse das partes envolvidas na relação processual foi paulatinamente perdendo força à medida do crescimento do reconhecimento da autonomia e da possibilidade de proteção para além das nuances adjetivas do processo. A consequência imediata desta tendência de mentalidade é a promoção do amadurecimento acerca da disposição dos sujeitos de direitos e deveres sobre os fatos jurídicos processuais, tornando-lhes o mais oportuno possível.

O novo modelo negocial trazido pelo CPC apenas consumou a inclinação acima traçada. Em respeito ao autorregramento da vontade das partes e à arrematação de atipicidade negocial sobre o processo, a legislação admite uma série de arranjos promovidos pelos interessados que lhes sejam mais convenientes, antes ou durante o processo. 
Paralelamente a essa noção, a legislação brasileira também entrega ao credor a faculdade de dispor sobre a execução ou acerca das medidas executivas. Ao tempo em que a ordem jurídica se preocupa com a efetividade dos provimentos e a total satisfação creditícia, também atribui à livre disposição do exequente o interesse do exercício da pretensão executória.

Sob essas considerações introdutórias que o estudo relativo à negociação processual em torno da astreinte deve ser procedido. A multa coercitiva, como oportunamente será mais bem desenvolvido, consiste em medida que atinge o patrimônio do obrigado na hipótese do não cumprimento da ordem, constrangendo-lhe, então, através da ameaça em pecúnia, a uma conduta. Sendo assim, questiona-se: é possível que as partes negociem sobre o valor da multa, seja antes ou depois de eventual consolidação do débito? E sobre a periodicidade? Demais critérios de fixação também podem ser acordados pelos interessados? É possível arranjar as hipóteses de incidência ou de exigibilidade do montante mensurado? O credor da multa também pode ser modificado? Dentre outras, são reflexões que merecem ser pensadas adequadamente, tendo em vista as consequências práticas que se apresentam.

Para tal finalidade, deverão ser analisados os axiomas que propiciem a posterior conclusão na tentativa de respostas. De início, serão observados os pressupostos que tornam a negociação jurídica processual possível em sede de execução, isto por conta do respeito ao autorregramento da vontade das partes pela própria estruturação sistêmica, pela atipicidade negocial erigida na ordem processual e, por fim, pela opção legal da disponibilidade executiva atribuída ao exequente.

Feita essa exploração, será discorrida a natureza jurídica da multa coercitiva objeto de estudo, no intuito de conferir a ela viabilidade negocial, isto porque doutrina especializada no assunto diverge sobre a matéria e o desfecho implica o atingimento da possibilidade de acordo em torno dos aspectos da astreinte.

Quando finalmente ultrapassadas as considerações conceituais promovidas através de peritos no assunto, buscar-se-á, em conclusão, esboçar dedutivamente a possibilidade da realização de negócio jurídico processual sobre os pormenores da multa coercitiva, tarefa que ora se inicia.

\section{Autorregramento das Partes sobre a Execução}

A execução civil tem a precípua finalidade de tornar factível direito já reconhecido substancialmente, isto é, entregar na realidade o que se assegura anteriormente ao detentor de direito material. Não por outra razão se afirma que a tutela jurisdicional, quando pensada na perspectiva do direito material, exige resposta de resultado que é proporcionado pelo processo no plano material. ${ }^{1}$

Assim, é possível falar no princípio da tutela judicial efetiva, que requer procedimentos de execução acessíveis para as partes, sem obstáculos ou demoras indevidas, viabilizando a materialização da proteção do direito reconhecido no pronunciamento judicial, pois a efetividade das decisões depende de sua execução. A atividade executiva faz parte da conexão entre Constituição e processo, guardando uma conexão com os direitos fundamentais e a Constituição. ${ }^{2}$

Inclusive, a valorização pelo processo de resultados é patente, dando-lhe prestígio de acordo com a sua capacidade de ser útil em ofertar ao direito material a solução de problemas ${ }^{3}$, pressupondo-se "uma nova concepção de mecanismos de proferimento, de atuação e de realização concreta das decisões judiciais (de técnicas processuais)."

1 MARINONI, Luiz Guilherme. Técnica processual e tutela dos direitos. 6. ed. rev. e atual. São Paulo: Thomson Reuters Brasil, 2019, p. 99.

2 ZANETI Jr., Hermes. Comentários ao código de processo civil. Vol. XIV, 2. ed. São Paulo: Revista dos Tribunais, 2018, p. 55.

3 FONSECA E SILVA, Augusto Vinícius. Princípios pamprocessuais ou metaprocessuais. Salvador: Editora Juspodivm, 2019, p. 80 .

4 REALE, Ana Luísa Fioroni. A multa astreinte como importante medida de apoio, prevista no ordenamento jurídico brasileiro, diante do artigo 139, IV, do novo Código de Processo Civil. Dissertação de Doutorado em Direito. São Paulo: Pontifícia Universidade Católica de São Paulo, 2016, p. 32. 
Ainda nesse ínterim, insta enfatizar que a efetividade da execução, através da atividade satisfativa, busca fundamento constitucional na matriz do acesso à justiça, de modo que o Estado deve possuir meios idôneos para o asseguramento da tutela jurisdicional, concluindo-se, nessa linha de pensamento, que o acesso à justiça resta desfigurado se apartado da análise das técnicas processuais. ${ }^{5}$ Justamente por esse sentido que Luiz Guilherme Marinoni ${ }^{6}$ chega a asseverar que "o direito à prestação jurisdicional efetiva já foi proclamado como o mais importante dos direitos, exatamente por constituir o direito a fazer valer os próprios direitos."

Dadas as premissas iniciais, cumpre observar que os atos executivos devem ser praticados no interesse do credor, tendo em vista que essa é a razão de ser componente do procedimento executório. Outro entender seria esvaziar a função elementar da prática executiva.

Em tal contexto, o magistrado deve observar a menor onerosidade não como uma cláusula geral de proteção ao executado, visto que esta incide na análise da adequação e necessidade do meio menos oneroso, não no resultado alcançado. ${ }^{7} \mathrm{O}$ constrangimento do devedor é da substância do procedimento executivo, e tal constatação deve nortear o embate entre a dignidade do devedor e o direito à efetivação dos direitos do credor $^{8}$, a fim de que se possa reverter a constatação de Francesco Carnelutti ${ }^{9}$, quando afirmou que há muito tempo a posição do credor, não apenas no campo penal, como também na execução civil, encontra-se bem menos tutelada do que a posição do devedor.

No entanto, em nenhuma hipótese isso significa o arbítrio ou autoritarismo processual. Bem pelo contrário, na verdade, toda execução deve estar atenta às balizas oferecidas pelo devido processo legal. Sobre o que agora se defende, Humberto Theodoro Jr. ${ }^{10}$ é categórico ao elucidar que a execução deve tender apenas à satisfação do direito do credor, limitando-se ao estritamente necessário, bem como deve ser norteada pela utilidade executiva, impedindo que se transforme em instrumento de castigo ou sacrifício ao devedor.

Paralelamente ao que até então se dispôs, não restam dúvidas acerca da possibilidade de gestão negocial da execução no direito brasileiro. Sobre esse ponto, Pedro Henrique Nogueirall apresenta a principal tríade de fundamentação, qual seja: há norma de respeito ao autorregramento da vontade no processo, cláusula geral de atipicidade da negociação processual e regime de disponibilidade da execução forçada.

Acerca dos dois primeiros, que aqui serão apreciados em conjunto, tem-se que a nova legislação processual teve o claro intuito de fomentar a participação dos envolvidos no deslinde de suas controvérsias. Ora, ninguém melhor que os próprios interessados para dirimir os entraves que se apresentem.

Rodrigo Ramina de Lucca $^{12}$ afirma, inclusive, que o princípio dispositivo decorre da autonomia privada das partes e da liberdade que lhes é conferida para autorregrar os seus próprios interesses, traduzindo a liberdade individual no âmbito jurisdicional-processual. Ainda conforme o autor, o Direito Processual é um instrumento de liberdade e segurança erigido em benefício do jurisdicionado a fim de

5 DOUTOR, Maurício Pereira. Medidas executivas atípicas na execução por quantia certa: diretrizes e limites de aplicação. Dissertação de Mestrado. Curitiba: Universidade Federal do Paraná, 2019, p. 36 e 38.

6 MARINONI, Luiz Guilherme. Técnica processual e tutela dos direitos. 6. ed. rev. e atual. São Paulo: Thomson Reuters Brasil, 2019, p. 128.

7 DIDER Jr., Fredie; CUNHA, Leonardo Carneiro da; BRAGA, Paula Sarno; OLIVEIRA, Rafael Alexandria de. Curso de direito processual civil: execução. 7ํㅡㄹ Ed. Salvador: Juspodivm, 2017, p. 78 a 91.

8 MINAMI, Marcos Youji. Da vedação ao non factibile: uma introdução às medidas executivas atípicas. Salvador: Juspodivm, 2019, p. 33.

9 CARNELUTTI, Francesco. Sistema de direito processual civil. São Paulo: Classic Book, 2000 , p. 303.

10 THEODORO Jr., Humberto. Curso de direito processual civil - vol. III. 50. ed. rev., atual. e ampl. Rio de Janeiro: Forense, 2017, p. 225 e 226.

11 NOGUEIRA, Pedro Henrique. Gestão da execução por meio de negócios jurídicos processuais no processo civil brasileiro. Revista de Processo, v. 286, p. 325-342, dez. 2018, p. 01.

12 LUCCA, Rodrigo Ramina. Disponibilidade processual: a liberdade das partes no processo. São Paulo: Revista dos Tribunais, 2019, p. 39 a 43. 
que a este sejam concebidas esferas de liberdade para que possa tomar as decisões que lhe pareçam mais adequadas.

Sob esta ótica, a sistematização intenta aproximar a vontade das partes para o mais adequado desfecho da situação jurídica apresentada, seja através da composição meritória ou das adaptações formais. A respeito das formas, aliás, há muito tempo que se atenta para a necessidade de evitar a formalidade como obstáculo à consecução do propósito processual, ainda que se reconheça a importância da forma como garantias de ordem, certeza e eficiência. ${ }^{13}$

Nesse âmbito, pondera Carlos Alberto Alvaro de Oliveira ${ }^{14}$ no sentido de que não merecem acolhimento tanto o sistema de absoluta liberdade da forma para as partes, quanto o da ilimitada soberania do juiz, pois ambos podem conduzir à desordem do processo e à insegurança.

A consequência de tais reflexões levou ao inevitável incentivo às partes pela autonomia e autorregramento da vontade. Pressupondo-se um espaço de liberdade, o ordenamento brasileiro se estruturou, portanto, em primazia à autocomposição, e não apenas no sentido de promover e incentivar, mas, também, de abster-se de interferir nas soluções arranjadas pelas partes. ${ }^{15}$

Nessa perspectiva, o congraçamento legal em relação à vontade dos sujeitos propicia o incremento de liberdade para que estes deem a si mesmos soluções alternativas para seus próprios problemas, numa chamada abertura para a consensualidade. ${ }^{16}$ A ínsita repercussão desse fenômeno tem a virtude de promover, ao menos, maior grau de envolvimento dos interessados diante da viabilidade de arranjamento no processo.

O acabamento processual acima referido apenas espelha a tendência resultante da crise da atividade jurisdicional, conjuntura que instigou, sobretudo, a permissão aos sujeitos de flexibilização dos procedimentos ou alteração das formas processuais. ${ }^{17}$ Contudo, independentemente das razões, que possuem, logicamente, relevância crucial para a fundamentação do modelo vigente, fato é que o autorregramento da vontade se faz presente estruturalmente no CPC, vide os arts. $3^{\circ}, 2^{2}$, 139 , V e 190 .

Acerca da cláusula geral de atipicidade da negociação processual, disposta no art. 190, do CPC, deve-se realçar a novidade do dispositivo no direito brasileiro, muito reflexo do que acima já se discorreu. O preceito mencionado estabelece a possibilidade de as partes estipularem mudanças no procedimento conforme as especificidades da causa, permitindo, ademais, a convenção sobre os ônus, poderes, faculdades e deveres processuais, antes ou durante o processo.

A técnica legislativa de textura aberta apenas proporciona "a necessária coexistência entre o texto legal e as práticas sociais". ${ }^{18}$ Relevante apontar, ainda sobre as cláusulas gerais, que a abertura linguística exerce importantes funções, pois permite a criação de normas casuísticas, assegura a flexibilidade do sistema a responder novos fatos e demandas, assim como contribui para a integração do ordenamento. ${ }^{19}$

13 GAJARDONI, Fernando da Fonseca. Flexibilidade procedimental: um novo enfoque para o estudo do procedimento em matéria processual. Tese de Doutorado. São Paulo: Universidade de São Paulo, 2007, p. 153.

14 OLIVEIRA, Carlos Aberto Alvaro de. Do formalismo no processo civil: proposta de um formalismo-valorativo. 4. ed. São Paulo: Saraiva, 2010, p. 168 a 170.

15 NOGUEIRA, Pedro Henrique. Negócios jurídicos processuais. 3. ed. rev., ampl. e atual. Salvador: Editora JusPodivm, 2018, p. 261.

16 CORDEIRO, Adriano Consentino. Negócios jurídicos processuais e as consequências do seu descumprimento. Tese de Doutorado. Curitiba: Universidade Federal do Paraná, 2016, p. 97 e 98.

17 ALMEIDA, Diogo Assumpção Rezende de Almeida. Das convenções processuais no processo civil. Tese de Doutorado, Faculdade de Direito. Rio de Janeiro: Universidade do Estado do Rio de Janeiro, 2014, p. 103.

18 FILHO, Ruy Alves Henriques. As cláusulas gerais no processo civil. Revista de Processo. v. 155, p. 335-364, jan. 2008, p. 03 .

19 BORGES, Marcus Vinícius Motter. Medidas coercitivas atípicas nas execuções pecuniárias: parâmetros para a aplicação do art. 139, IV do CPC/15. São Paulo: Thomson Reuters, 2019, p. 85. 
Rodrigo Reis Mazzei ${ }^{20}$ afirma que o legislador, no intuito de propiciar a aplicação da lei por um período mais duradouro, recorreu ao uso de cláusulas gerais, entendidas como normas lançadas em forma de diretrizes, dirigidas ao Estado-juiz, que deverá, conforme o que foi previamente traçado pelo próprio legislador, dar a solução mais acertada ao caso trazido a juízo, observando para a concretização da atuação judicial não apenas o critério objetivo, mas as situações particulares que envolvem cada caso. Isso não quer dizer, todavia, que o sistema abriu mão do conceitualismo, mas que há uma busca pelo balanceamento entre dispositivos legais fechados (casuísticos) e hipóteses legais para preenchimento (cláusula geral), evitando o fechamento do sistema, assim como a diminuição da incerteza que pode ser gerada por um diploma que contenha apenas cláusulas gerais.

Para José Carlos Barbosa Moreira ${ }^{21}$, a fixação dos conceitos juridicamente indeterminados abre ao aplicador da norma certa margem de liberdade, certa subjetividade. Adverte, outrossim, que não se deve confundir tal fenômeno com a discricionariedade. Um e outro tem em comum a necessidade da prudência por parte do aplicador. No entanto, a diferença fundamental reside em que os conceitos indeterminados integram a descrição do fato, ao passo que a discricionariedade se situa no campo dos efeitos.

Judith Martins-Costa ${ }^{22}$, ao seu turno, aponta dois critérios para a aplicação das cláusulas gerais. O primeiro está na adstrição ao direcionamento da delegação atribuída pelo legislador ao intérprete para que complete o enunciado, detalhando a hipótese normativa e desenvolvendo soluções jurídicas para os casos. No segundo critério, as pautas de valoração estão indicadas em outras disposições legais que fazem parte do sistema, ou são objetivamente vigentes no ambiente social em que o juiz opera.

Pela leitura do art. 190, do CPC, conclui-se pela consagração da cláusula geral de negociação processual, sendo permitida a formulação de negócios processuais atípicos ${ }^{23}$, entendendo-se que o negócio processual consiste em fato jurídico voluntário em que esteja conferido ao sujeito, no suporte fático, o poder de escolha da categoria jurídica ou a faculdade de estabelecer, dentro dos próprios limites normativos, certas situações jurídicas, subsistindo através de espaço deixado para a influência e participação na elaboração da atividade procedimental. ${ }^{24}$

É justamente o espaço de liberdade, concedido pelo sistema jurídico às pessoas na escolha das categorias jurídicas e na estruturação do conteúdo eficacial, que consiste no elemento fundamental do negócio jurídico, diferentemente de quando a vontade não tem escolha, com efeitos necessários já preestabelecidos. ${ }^{25}$ Outrossim, o destaque dado a esse elemento caracterizador do negócio jurídico é determinante para as limitações de controle de validade do juiz, que ficará adstrito somente às hipóteses legais, sem juízo de oportunidade e conveniência, ou seja, com uma função restrita a verificar se o negócio jurídico processual está de acordo com o ordenamento jurídico." ${ }^{26}$ Portanto, em regra, o negócio jurídico processual se presume válido e eficaz, cabendo ao juiz atuar, unicamente, no controle de sua validade. ${ }^{27}$

20 MAZZEI, Rodrigo Reis. Código civil de 2002 e o judiciário: apontamentos na aplicação das cláusulas gerais. In: DIDIER Jr. Fredie; MAZZEI, Rodrigo Reis. Reflexos do novo código civil no direito processual. Salvador: Juspodivm, 2006 , p. 29.

21 MOREIRA, José Carlos Barbosa. Temas de direito processual: segunda série. 2a ed. São Paulo: Saraiva, 1988 , p. 65 e 66.

22 COSTA, Judith Martins. A boa-fé no direito privado: critérios para a sua aplicação. 2a ed. São Paulo: Saraiva, 2018, p.

173.

23 DIDIER Jr., Fredie; CABRAL, Antonio do Passo. Negócios jurídicos processuais atípicos e execução. Revista de Processo, v. 275, p. 193-228, jan. 2018, p. 02.

24 DIDIER Jr., Fredie; NOGUEIRA, Pedro Henrique Pedrosa. Promessa de recompensa judicial. In ALVIM, Arruda (coord.) et al. Execução civil e temas afins - do CPC/1973 ao Novo CPC - estudos em homenagem ao professor Araken de Assis. São Paulo: RT, 2014, p. 08.

25 MELLO, Marcos Bernardes de. Teoria do fato jurídico: plano da existência, 11. ed. São Paulo: Saraiva, 2001 , p. 72

26 BOCALON, João Paulo. Os negócios jurídicos processuais no Novo Código de Processo Civil Brasileiro. Dissertação de Mestrado, Pontifícia Universidade Católica de São Paulo. São Paulo, 2016, p. 109.

27 AVELINO, Murilo Teixeira. A posição do magistrado em face dos negócios jurídicos processuais - já uma releitura. In.: CABRAL, Antonio do Passo; NOGUEIRA, Pedro Henrique (coords). Coleção Grandes Temas do novo CPC. v. 1. ed. 2. Salvador: JusPodivm, 2016, p. 381. 
Com efeito, rumando à construção do autorregramento da vontade nas execuções, o sistema jurídico processual é imperativo ao estabelecer a disponibilidade executória individual na ordem normativa brasileira, vide o art. 775, do CPC. Este estabelece que "o exequente tem o direito de desistir de toda a execução ou de apenas alguma medida executiva."

Quer-se dizer que fica ao livre interesse do credor a possibilidade de desistência total ou parcial da execução ou das medidas executivas, em verdadeiro caráter de distribuição de autonomia relativa a sua melhor conveniência.

Cumpre destacar que o CPC/73 já dispunha sobre a disponibilidade da execução, visto que o art. 569 do antigo diploma estabelecia tal faculdade. No entanto, o novo CPC traz nova redação que apenas reforça a ideia de voluntariedade, que terá não apenas a faculdade, como no regime anterior, mas genuíno direito. ${ }^{28}$

A conclusão lógica do raciocínio permite arrematar, portanto, que a execução também é campo propício para a negociação processual. A junção de todas as sustentações feitas acima permite ultimar pela total viabilidade da gestão negocial. Nos dizeres de Pedro Henrique Nogueira ${ }^{29}$, "como a disponibilidade é um poder conferido ao exequente, fica clara também a possibilidade de haver acordos processuais (negócios jurídicos processuais bilaterais) celebrados com o executado em torno dela.”

Acrescente-se, também, a ideia de que a execução se volta para os interesses creditícios em respeito aos limites impostos pelo sistema de atingimento da esfera jurídica do executado. Em sendo do melhor interesse das partes, na busca pelo processo de resultados, efetivo e que mais convenha à vontade dos envolvidos, nada mais justo - com o devido uso do termo - que a negociação processual esteja assegurada sobre variáveis aspectos da execução.

Evidentemente que a ilação acima proposta consiste em novidade jurídica, o que enseja alguns contrapontos, ressalvas e inquietações. No entanto, se de um lado a formalidade jurisdicional voltada à execução é de elevado valor, com a dignidade da pessoa do devedor em estimada valia, a efetividade dos atos executivos e o respeito à autonomia das partes não podem ser deixados de lado e desconsiderados da equação, vez que também são valores endossados pelo sistema processual. ${ }^{30}$

Traçados os pressupostos que permitem concluir pela possibilidade de negociação processual na execução civil, indaga-se, nesse momento, sobre a eventualidade de também se negociar a respeito das multas coercitivas, as denominadas astreintes.

A proposta se revela importante porque a sua aceitação não é pacífica. Tomem-se Fredie Didier Jr. e Antônio do Passo Cabral ${ }^{31}$, que, apesar de defenderem a viabilidade da gestão negocial nas execuções, entendem que as partes não podem deliberar, por convenção, que o juiz não utilizará alguns meios de coerção, e que não podem, por exemplo, limitar o valor das astreintes.

Rafael Caselli Pereira ${ }^{32}$, ao seu turno, também não admite que as partes interfiram no poder do Estado-Juiz para vedar a possibilidade de fixação da referida multa judicial ou para transfigurar os critérios de fixação e posterior consolidação do quantum.

No entanto, com as devidas considerações aos divergentes, não parece haver qualquer tipo de limitação de disponibilidade a respeito da multa coercitiva, senão os limites de validade para a configuração do próprio negócio jurídico processual. Para que se corrobore esse entendimento, faz-se

28 DONIZETTI, Elpídio. Novo Código de Processo Civil comentado. 2. ed. rev., atual. e ampl. São Paulo: Atlas 2017 , p. 969.

29 NOGUEIRA, Pedro Henrique. Gestão da execução por meio de negócios jurídicos processuais no processo civil brasileiro. Revista de Processo, v. 286, p. 325-342, dez. 2018, p. 04.

30 GAJARDONI, Fernando da Fonseca; DELLORE, Luiz; ROQUE, André Vasconcellos; OLIVEIRA Jr., Zulmar Duarte de. Execução e recursos: comentários ao CPC de 2015, v. 3. 2. ed. Rio de Janeiro: Forense; São Paulo: Método, 2018, p. 28.

31 DIDIER Jr., Fredie; CABRAL, Antonio do Passo. Negócios jurídicos processuais atípicos e execução. Revista de Processo, v. 275, p. 193-228, jan. 2018, p. 08.

32 PEREIRA, Rafael Caselli. A multa judicial (astreinte) e o CPC/2015. 2. ed. rev. e ampl. Porto Alegre: Editora Livraria do Advogado, 2018, p. 355. 
necessário compreender a natureza jurídica da astreinte, a fim de que a partir da delimitação conceitual seja possível concluir pela viabilidade de negócio em torno dos seus aspectos.

\section{Natureza Jurídica da Astreinte}

Para que se ateste a possibilidade de negócio processual em torno dos aspectos da astreinte, tarefa elementar consiste no esboço em torno da natureza jurídica da referida multa.

Primeiramente, insta categorizar a astreinte enquanto medida coercitiva e desprovida de caráter ressarcitório, vez que aquela consiste em forma de coerção psicológica do executado e convive perfeitamente com as perdas e danos.$^{33}$ Primeiro que o art. 500, do CPC, dispõe que a indenização por perdas e danos dar-se-á sem prejuízo da multa periódica. Segundo que o art. 537, também do CPC, estabelece que a multa deverá ser suficiente e compatível com a obrigação, o que implica afirmar a total ausência de balizamento teórico de valores.

Assim, na de lição Newton Coca Bastos Marzagão ${ }^{34}$, o objetivo da astreinte é o de superar a resistência do devedor, constrangendo-lhe psicologicamente a uma conduta. O mesmo conceito pode ser extraído da doutrina francesa - originária da multa -, a qual indica que "a astreinte é uma ordem pecuniária pronunciada pelo juiz e destinada a superar a resistência de um devedor recalcitrante.”35

Até mesmo a gênese da medida revela o caráter da coerção que lhe reflete. Na legislação oitocentista francesa, em virtude das noções protetivas em face do Estado e da intangibilidade pessoal, que impedia o uso de coerção contra o indivíduo, as obrigações dependentes de conduta se resolviam em perdas e danos quando do inadimplemento, situação que levou o labor jurisprudencial a desenvolver multa desvinculada da indenização, tão somente na função de induzir o devedor a um cumprimento. ${ }^{36}$

Como se disse de início, ponto importante para atestar a possibilidade de negócio sobre a astreinte está na sua natureza jurídica. É que a argumentação que ampara a impossibilidade para tanto gira em torno da inviabilidade de retirar o império estatal, isto é, a força jurisdicional de fazer valer seus comandos. Em outras palavras, a justificativa basilar para a impossibilidade de negócio processual em torno das astreintes consiste na razão de ser da multa, isto porque ela supostamente consiste em técnica de poder que pode ser aplicada, inclusive, independentemente de requerimento das partes.

Conforme preleciona Araken de Assis ${ }^{37}$, por exemplo, a astreinte é multa pecuniária caracterizada pela exorbitância, dotada de duplo objetivo, ou seja, o de proteger o direito litigioso e resguardar a dignidade do ofício judiciário.

Guilherme Rizzo Amaral ${ }^{38}$ chega a afirmar que "admitir a renúncia a uma das formas de intervenção do poder jurisdicional estatal parece implicar violação ao princípio da inafastabilidade do Poder Judiciário", concluindo, ademais, que a astreinte não poderia ser limitada por livre disposição das partes.

Marcelo Lima Guerra ${ }^{39}$, no final do século passado e em total consonância com a visão acima delineada, conclui que:

33 ABELHA, Marcelo. Manual da execução civil. 5. ed. rev. e atual. Rio de Janeiro: Forense, 2015 , p. 305 e 307.

34 MARZAGÃO, Newton Coca Bastos. A multa (astreintes) na tutela específica. Dissertação de mestrado, Faculdade de Direito. São Paulo: Universidade de São Paulo, 2013, p. 114.

35 CHABAS, François. L'astreinte em droit français. Doutrinas essenciais Obrigações e Contratos, v. 2, p. 1159-1164, jun. 2011, p. 01. No original: "l'astreinte est une condamnation pécuniaire prononcée par le juge et destinée à vaincre la résistance d'un débiteur récalcitran."

36 MEDINA, José Miguel Garcia. Execução: Teoria Geral, princípios fundamentais e procedimento no processo civil brasileiro. 5. ed. rev., ampl. e atual. São Paulo: Editora Revista dos Tribunais, 2017, p. 317.

37 ASSIS, Araken de. Comentários ao código de processo civil. Vol. XIII, 2. ed. São Paulo: Revista dos Tribunais, 2018, p. 156.

38 AMARAL, Guilherme Rizzo. As astreintes e o processo civil brasileiro: multa do artigo 461 do CPC e outras. 2 . ed. rev. atual. e ampl. Porto Alegre: Livraria do Advogado Editora, 2010, p. 177 e 179.

39 GUERRA, Marcelo Lima. Execução indireta. São Paulo: Editora Revista dos Tribunais, 1998, p. 200 e 201. 
(...) não se coaduna com a sistemática da atual disciplina das medidas coercitivas, principalmente da multa diária, qualquer entendimento que pretenda vincular os poderes do juiz, nessa matéria, à vontade das partes, principalmente quando essa vinculação conduza a uma virtual diminuição de eficácia coercitiva dessas medidas. Se assim fosse, ter-se-ia de admitir a possibilidade de as partes vedarem, no negócio jurídico que viesse a constituir em título extrajudicial, a aplicação da multa diária, o que parece flagrantemente incompatível com o caráter público do instituto.

Dessa forma, se ao juiz é lícito fixar multa diária independentemente de pedido da parte, não parece razoável entender-se que ele estaria vinculado ao acordo de vontade das partes, seja quanto à aplicação ou não da multa, seja quanto ao seu valor, especificamente para não aumentá-lo, verificado que ele tenha se tornado insuficiente.

Também Rafael Caselli Pereira ${ }^{40}$ defende a ideia de que se a multa judicial é forma de garantia de atendimento ao comando judicial previamente estabelecido, não podem as partes interferir em tal poder.

Ocorre que a natureza jurídica da astreinte não está vinculada propriamente ao resguardo da ordem judicial, tampouco tem a finalidade substancial de assegurar o cumprimento dos comandos judiciais para a proteção da força estatal. Na verdade, a coercibilidade inerente à multa em comento diz respeito unicamente ao efetivo cumprimento de conduta desejada. A distinção é extremamente sensível, mas guarda repercussões importantes.

O próprio Guilherme Rizzo Amaral ${ }^{41}$, por exemplo, em resposta a Sérgio Arenhart, assinalou que não parece ser o entendimento dominante que a astreinte seja medida voltada a resguardar a autoridade das decisões, isto porque historicamente, com raras exceções, elas foram tratadas como medida eminentemente coercitiva. Na discussão aqui trazida, Arenhart ${ }^{42}$ comparou as astreintes, enquanto meio coercitivo, com os inherent powers norte-americanos, afirmando que as medidas executivas buscam também garantir as próprias decisões, numa espécie de punição pela desobediência judicial.

Evidentemente que a multa coercitiva tem a finalidade de compelir o atingido ao cumprimento de ordem judicial, mas não pela noção de resguardo da decisão, e sim tão somente pelo efetivo cumprimento esperado, que é o verdadeiro intuito da astreinte. O natural resguardo da ordem judicial é mera consequência.

Apenas a título de reforço do que aqui se entende, a legislação processual já traz consigo as consequências do ato atentatório à dignidade da justiça e ao litigante de má-fé, vide os arts. 77, IV, e 80, IV, ambos do CPC.

A disciplina traçada no art. 537, do CPC, portanto, aborda a multa aqui mencionada como "técnica de tutela coercitiva a acessória, que visa pressionar o réu para que este cumpra mandamento judicial, sendo a pressão exercida através de ameaça ao seu patrimônio."43

Consequentemente, não encontra guarida o entendimento da impossibilidade de negócio em torno da astreinte fundado no declínio do império estatal, pois na prática dos atos executivos, como se demonstrou, a multa coercitiva não tem o condão de proteger decisões e ordens, mas tão somente induzir um sujeito de dever a um comportamento em favor do credor. A proteção citada, caso ocorra, é decorrência lógica do instituto.

40 PEREIRA, Rafael Caselli. A multa judicial (astreinte) e o CPC/2015. 2. ed. rev. e ampl. Porto Alegre: Editora Livraria do Advogado, 2018, p. 355.

41 AMARAL, Guilherme Rizzo. As astreintes e o novo Código de Processo Civil. Revista de Processo, São Paulo: Revista dos Tribunais, v. 35, n. 182, p. 181-214, abr. 2010, p. 08 e 09.

42 ARENHART, Sérgio Cruz. A doutrina brasileira da multa coercitiva - três questões ainda polêmicas. In MEDINA, José Miguel Garcia; CRUZ, Luana Pedrosa de Figueiredo; CERQUEIRA, Luis Otávio Sequeira; GOMES JUNIOR, Luiz Manoel (coord.). Os poderes do juiz e o controle das decisões judiciais - estudos em homenagem à Professora Teresa Arruda Alvim Wambier. São Paulo: Revista dos Tribunais, 2008, p. 02 e 03.

43 AMARAL, Guilherme Rizzo. Do cumprimento de sentença que reconheça a exigibilidade de obrigação de fazer, de não fazer ou de entregar coisa. In WAMBIER et al. (Coord.). Breves comentários ao novo Código de Processo Civil. São Paulo: Editora Revista dos Tribunais, 2015, p. 1404. 
De toda forma, ainda que essa inteligência reste superada, não há óbice para que se negocie sobre a multa coercitiva. Ou seja, ainda que se compreenda ser ela medida à disposição do Poder Judiciário para proteger o império e a força das ordens, a sistemática atual da ordem processual não apresenta obstáculo para o negócio.

Utilizando-se da máxima in eo quod plus est semper inest et minus, quem pode o mais, pode o menos. Soa inimaginável que o interessado possa dispor unilateralmente de toda a execução ou de qualquer medida executiva, nos termos do art. 775, do CPC, mas não possa negociar sobre elas em franca liberdade.

Como amplamente exposto, a execução é realizada e procedida em favor do credor. Por conseguinte, fica a seu critério "decidir e abrir mão da prática de atos executivos, expropriatórios ou não, que possam vir a ser praticados no procedimento executório". ${ }^{44}$ Apenas para concluir o raciocínio, Araken de Assis ${ }^{45}$ define que o caput do art. 775, CPC, consagra o princípio da disponibilidade da execução, apontando que a atividade satisfativa apenas beneficia o exequente e, no máximo, o executado deixa de perder.

Na lição de Teori Albino Zavascki ${ }^{46}$, também ao analisar o artigo 775, CPC, "a execução tem por única finalidade a satisfação do crédito, de modo que sua razão de ser está relacionada exclusivamente ao interesse e ao proveito do credor, que dela pode dispor."

A imposição judicial de ofício da multa em nada afasta a possibilidade de negócio processual em torno dela. Ora, a atipicidade negocial e o incentivo ao autorregramento da vontade permitem o referido arranjo, considerando que o elemento completante do suporte fático é exatamente o poder de determinação e regramento da categoria jurídica. ${ }^{47} \mathrm{~A}$ astreinte estabelecida para o cumprimento de ordem em favor do exequente claramente está à disposição do próprio exequente, máxime o fato de que o valor obtido da multa constitui seu crédito, com fulcro no art. 537, § 2º, do CPC.

Deve-se atentar, ainda, que mesmo independendo de requerimento para sua fixação, o valor ou a periodicidade da multa vincenda podem ser modificados ou excluídos, nos termos do 537, § 1º, do CPC, o que somente corrobora a noção de flexibilização.

Ao tempo em que a execução deve se pautar pela máxima utilidade, pelo respeito às legítimas agressões ao patrimônio do executado, pelos resultados a serem obtidos no plano fático, pela disponibilidade, pela menor onerosidade, e, paralelamente, pelo autorregramento dos envolvidos, nada mais sublime que a autorização interpretativa de negócio jurídico processual atípico sobre todo e qualquer aspecto em torno da astreinte.

Impedir a negociação em torno da referida multa coercitiva seria colocar empecilho onde não há, tendo em vista que os fatores aqui levantados em favor da disponibilidade executiva e da liberdade negocial incidem justamente sobre o que é disponível. Rigorosamente, os acordos apenas valorizam o diálogo entre juiz e as partes, fomentando o processo civil democrático. ${ }^{48}$

Relativamente ao processo civil democrático, urge endossar a cooperação como norma fundamental habitada na sistematização processual, aplicável a todos os procedimentos e, naturalmente, à execução, superando os modelos adversarial e inquisitivo. Nesse sentido, sob a concepção de um modelo de execução democrático, a cooperação mais que informa, vez que constitui a própria organização do processo dentro dos parâmetros de boa-fé e lealdade em busca da duração razoável e efetividade. ${ }^{49}$

44 NOGUEIRA, Pedro Henrique. Gestão da execução por meio de negócios jurídicos processuais no processo civil brasileiro. Revista de Processo, v. 286, p. 325-342, dez. 2018, p. 04.

45 ASSIS, Araken de. Processo Civil brasileiro - volume IV (livro eletrônico): Manual da Execução. São Paulo: Editora Revista dos Tribunais, 2016, p. 723.

46 ZAVASCKI, Teori. Comentários ao código de processo civil. Vol. XII, 2. ed. São Paulo: Revista dos Tribunais, 2018 , p. 52.

47 ATAÍDE Jr., Jaldemiro Rodrigues de. Negócios jurídicos materiais e processuais - Existência, validade e eficácia Campo-invariável e campos-dependentes: sobre os limites dos negócios jurídicos processuais. Revista de Processo. v. 244 , jun. 2015, p. 06.

48 NOGUEIRA, Pedro Henrique. Gestão da execução por meio de negócios jurídicos processuais no processo civil brasileiro. Revista de Processo, v. 286, p. 325-342, dez. 2018, p. 03.

49 DURO, Cristiano. Execução e democracia. Salvador: Juspodivum, 2018, p. 230 e 231. 
Ainda na perspectiva de processo democrático e cooperativo, há flagrante necessidade de rompimento da demasiada crença publicista processual em desfavor da liberdade dos jurisdicionados, mostrando-se imperioso o abandono pela "falsa ideia de que o Estado sabe melhor o que deve querer o indivíduo." ${ }^{50}$

Assim, tem-se que o negócio jurídico processual, além de ser permitido pelos fundamentos autorizadores encontrados no próprio sistema, também encontra respaldo na cooperação exigida entre todos os envolvidos da relação executória. Se os interessados pela execução resolvem dispor sobre medida coercitiva - o exequente que detém o crédito e o executado que deseja se resguardar da afetação patrimonial -, não há prudência em impedir.

O controle do juiz sobre a convenção processual celebrada ficará limitado a defeitos pertinentes ao próprio negócio, mas jamais com base em critérios de conveniência ou oportunidade, analisando se o negócio realizado é ou não de seu agrado pessoal. ${ }^{51}$

Ainda nessa ordem de ideias, é à luz da cooperação que se outorga o novo papel do juiz na condução do processo, tendo por escopo o desenvolvimento de um processo justo e isonômico, erigindo, ao final, uma comunidade de trabalho. ${ }^{52}$

Destarte, mostra-se inequívoca a justeza e isonomia na negociação processual válida sobre aspecto disponível dentro da execução, que é o caso da astreinte, conforme defendido.

\section{Aspectos da Negociação da Astreinte}

Entregues os pressupostos que permitem a ampla negociação em torno da astreinte, conclui-se que todos os seus aspectos são passíveis de acordo por meio de negócio jurídico processual. Mais que isso, alguns negócios podem ser praticados unilateralmente pelo exequente, conforme a disponibilidade que lhe cabe, ou pelo próprio juiz nos seus limites de atuação. É o que se passa a demonstrar.

Apenas na tentativa de seguir uma sequência metodológica, primeiro se imiscui sobre a viabilidade de negócio jurídico unilateral pelo próprio juiz da execução. Como cediço, a fixação da multa coercitiva naturalmente perpassa pelo poder judicial, cabendo a este a determinação da medida e suas respectivas nuances, tais quais a incidência, o valor e a periodicidade.

Ainda sob a égide do CPC/73, Fredie Didier Jr. e Pedro Henrique Nogueira ${ }^{53}$ já defendiam que nada impedia que o juiz, por exemplo, realizasse promessa de recompensa judicial - negócio jurídico processual unilateral atípico à época - para estipular a incidência de multa por determinada fração temporal em estimado valor, estabelecendo, em contrapartida, isenções ou reduções no valor da astreinte em função do momento de cumprimento da decisão.

No novo CPC, apesar das modificações referentes ao regime da multa em comento, outro entendimento não se afigura bem visto. Ora, se a modificação ou exclusão de valores e periodicidade podem ser realizadas por permissivo legal, de ofício ou a requerimento, nos termos do art. 537, do CPC, o que dizer, então, quando da realização de negócio jurídico processual? Evidentemente que se esse fato jurídico processual partir do juiz, as partes interessadas deverão participar e influir na decisão, assegurando-se o contraditório e atestando a validade do negócio.

$50 \quad$ NERY, Carmen Lígia Barreto de Andrade Fernandes. O negócio jurídico processual como fenômeno da experiência jurídica - Uma proposta de leitura constitucional adequada da autonomia privada em processo civil. Tese de Doutorado em Direito. São Paulo: Pontifícia Universidade Católica de São Paulo, 2016, p. 41 e 42.

51 REDONDO, Bruno Garcia. Negócios jurídicos processuais atípicos no Direito Processual Civil brasileiro: existência, validade e eficácia. Tese de Doutorado em Direito. São Paulo: Pontifícia Universidade Católica de São Paulo, 2019 , p. 227.

52 FONSECA E SILVA, Augusto Vinícius. Princípios pamprocessuais ou metaprocessuais. Salvador: Editora Juspodivm, 2019, p. 290 e 291.

53 DIDIER Jr., Fredie; NOGUEIRA, Pedro Henrique Pedrosa. Promessa de recompensa judicial. In ALVIM, Arruda (coord.) et al. Execução civil e temas afins - do CPC/1973 ao Novo CPC - estudos em homenagem ao professor Araken de Assis. São Paulo: RT, 2014, p. 17. 
Seguindo o raciocínio de Pedro Henrique Nogueira ${ }^{54}$, "o espaço para o exercício do autorregramento da vontade é aquele deixado pelas normas cogentes." Outrossim, a disciplina cogente não parece ser o caso da astreinte. Se ela consiste em multa coercitiva, logo é medida executiva. Se há disponibilidade do exequente, logo se atesta possível dispô-la. As conclusões alavancadas seguem um percalço lógico.

Com efeito, é sedimentado que o crédito da astreinte pertence ao exequente. Consequentemente, através de negócio jurídico unilateral, ele pode pura e simplesmente renunciar à perseguição do crédito. Rafael Caselli Pereira ${ }^{55}$ possui esse mesmo entendimento ao dispor que poderá ser convencionada a não execução ou execução parcial da multa consolidada. Fredie Didier Jr. e Antônio do Passo Cabral ${ }^{56}$ endossam o pensamento, assinalando que as partes podem convencionar sobre a renúncia da cobrança da multa quando ela se converte em pecúnia.

Vale destacar, por oportuno, que se está a falar da renúncia à perseguição executiva do crédito, ou seja, referente ao espaço de liberdade concedido pela disponibilidade executória. Por outro lado, se o crédito, afinal, pertence ao próprio exequente, também nada impede sua livre disposição negocial, para além da mera disposição sobre a execução.

Atentando-se para os pressupostos delineados alhures, nada impede que as partes convencionem as sobre condições de exigibilidade de eventual quantia consolidada de multa coercitiva.

No entanto, divergindo dos autores acima mencionados, o mesmo juízo deve ser feito em relação à renúncia prévia de tal medida, pois é de critério e disponibilidade do exequente a utilização de medidas executivas, ou seja, o exequente pode negociar inclusive sobre a possibilidade de fixação.

Importa destacar mais uma vez que a efetividade processual deve clarear a tutela jurisdicional em correspondência com as tutelas materiais prometidas, de modo que se por vontade lícita alguém lançou mão de medida executiva, ele arcará com as consequências pelo próprio usufruto da liberdade, em nada afetando a efetividade do sistema executório. Ao contrário, o asseguramento do autorregramento da vontade, dentro dos critérios de validade do negócio, apenas aproximará a formalidade processual ao interesse dos envolvidos.

Essas problemáticas se acentuam ainda mais quando o negócio jurídico é celebrado unilateralmente, pois não há a noção de prestação recíproca que justifique a cedência ou ajuste na medida executiva. Todavia, a possibilidade de negócio jurídico bilateral celebrado com o executado pode oferecer vantagens legítimas como contrapartida da abdicação a ser negociada por parte do exequente, ou a submissão por parte do executado.

Rafael Caselli Pereira ${ }^{57}$, a título de exemplo, entende que as partes podem negociar sobre condições de incidência e até mesmo sobre hipóteses de revogação da astreinte, mas não podem dispor sobre os critérios de fixação e consolidação do quantum alcançado. Corroborando a intelecção, Didier Jr. e Antônio do Passo Cabral ${ }^{58}$ também indicam que as partes não podem, por convenção, limitar o valor das astreintes.

Entretanto, mais uma vez esse não parece ser o entendimento mais proveitoso. É incontroverso que o valor da multa coercitiva deve ser adequado para viabilizar a tutela jurisdicional em harmonia sistemática com os demais preceitos normativos, através de quantia suficiente para alcançar coerção e de

54 NOGUEIRA, Pedro Henrique. Negócios jurídicos processuais. 3. ed. rev., ampl. e atual. Salvador: Editora JusPodivm, 2018, p. 184.

55 PEREIRA, Rafael Caselli. A multa judicial (astreinte) e o CPC/2015. 2. ed. rev. e ampl. Porto Alegre: Editora Livraria do Advogado, 2018 , p. 354.

56 DIDIER Jr., Fredie; CABRAL, Antonio do Passo. Negócios jurídicos processuais atípicos e execução. Revista de Processo, v. 275, p. 193-228, jan. 2018, p. 08.

57 PEREIRA, Rafael Caselli. A multa judicial (astreinte) e o CPC/2015. 2. ed. rev. e ampl. Porto Alegre: Editora Livraria do Advogado, 2018, p. 355.

58 DIDIER Jr., Fredie; CABRAL, Antonio do Passo. Negócios jurídicos processuais atípicos e execução. Revista de Processo, v. 275, p. 193-228, jan. 2018, p. 08. 
modo que o atingido tenha condições de arcar com as consequências patrimoniais. ${ }^{59} \mathrm{O}$ negócio jurídico processual bilateral em torno do valor da astreinte é capaz de ir ao encontro dessas noções, considerando que as partes envolvidas serão diretamente afetadas e têm propriedade para adequar a medida conforme seus próprios interesses. Inclusive, o ajustamento de valor pode ser feito após a consolidação do débito ou antes mesmo da própria existência da relação executiva.

Imagine-se, também, que as partes possuam obrigações específicas infungíveis negociadas no plano material. Nada impede que, na hipótese de total inadimplemento, as mesmas negociem processualmente a incidência de astreinte como medida coercitiva para alguma(s), mas não para outra(s). A liberdade deve imperar e reger a vontade de quem se vincula validamente a um acordo.

Ainda sobre o exemplo acima mencionado, fica também à iniciativa das partes a negociação em torno da periodicidade que a multa incidirá, bem como sobre seu valor. Nesse ponto específico, cumpre ressaltar, apenas para que não restem dúvidas, que a astreinte em nada se confunde com a cláusula penal, não guardando qualquer relação entre dois institutos redondamente distintos. A ressalva se faz importante porque a negociação de multa pela mera hipótese de inadimplemento é diferente da negociação sobre multa coercitiva. Mais uma vez a natureza jurídica se revela extremamente necessária para afastar toda espécie de confusão.

Outra situação possível através da gestão da execução negociada diz respeito ao detentor do crédito, isto porque o art. 537, $\S 2^{\circ}$, do CPC, pode ser relativizado para que se destine o valor da multa a outro que não seja o exequente. Hipoteticamente a medida poderia ser dos interesses dos envolvidos e, como até então se defendeu, o autorregramento válido da vontade deve ser plenamente respeitado.

Em consumação, como se explanou ao longo deste trabalho, o campo para negociação em torno da astreinte é amplo, tendo em vista sua natureza e os pressupostos de respeito ao autorregramento da vontade presentes na execução, razões pelas quais o negócio jurídico processual celebrado em torno da multa coercitiva deve ser totalmente respeitado, desde que, logicamente, cumpra os requisitos de validade.

\section{Considerações Finais}

Ante o exposto, notou-se que o novo modelo processual sustentado pelo CPC engloba nas suas diretrizes o fomento pela flexibilização e aproximação da formalidade ao interesse das partes. Mais que isso, preza pelo autorregramento da vontade e pela amplitude negocial atípica, apenas reafirmando a busca de harmonização pelas conveniências disponíveis aos envolvidos.

Outrossim, a execução civil brasileira é qualificada, dentre outras características, pela disponibilidade. Além do caráter de flexibilização e autonomia amparado no atual sistema processual, essa conclusão é extraída categoricamente do art. 775, do CPC, o qual preceitua o direito do exequente em desistir de toda execução ou de alguma medida executiva específica. Com isso se diz que há liberdade oferecida ao credor sobre a execução, em autêntica distribuição de margem para conformidade casuística.

Admitidos esses argumentos, não se demonstra plausível a apresentação de óbices para o negócio jurídico processual em torno das multas coercitivas, designadas astreintes. Aliás, asseverou-se que doutrina especializada no assunto também ratifica esse entendimento, divergindo, contudo, quanto aos limites da negociação.

Todavia, quando vista a natureza jurídica da astreinte, aliada às demais considerações depreendidas no decorrer deste estudo, alternativa não resta senão concluir pela liberdade negocial em todos os aspectos inerentes à multa coercitiva. Por conseguinte, deve-se afirmar que o controle judicial sobre a convenção deve ficar limitado apenas pelos vícios que maculem a validade do negócio jurídico processual.

59 MARINONI, Luiz Guilherme. Tutela ressarcitória na forma específica. Revista de Processo, v. 300, fev. 2020 , p. 15. 
Ainda nesse sentido, fatores como os critérios de fixação, de exigibilidade, da determinação de valores, do impedimento de tomada da medida, da destinação do crédito a terceiro, das hipóteses de incidência ou de qualquer outro que porventura se relacione à multa coercitiva e seja válido negociar, como os que aqui foram defendidos, podem ser ajustados pelo melhor interesse disponível das partes.

Urge realçar, em vias de conclusão, que o processo não existe em função do Estado-Juiz. A instrumentalidade processual, apesar de autônoma e fundamental ao Estado Democrático de Direito, não pode ser perdida de vista. Se a finalidade executória reside na entrega de satisfação e efetividade a quem detém o direito substancial - no caso o credor/exequente -, não há razão para impedir que o mesmo possa negociar inclusive sobre matérias disponíveis a ele. A negociação processual, atrelada à exigência de maior flexibilização das formas aproximando-as das partes, é elemento que chegou para ficar, impondo-se uma revolução de mentalidade.

\section{Referências}

ABELHA, Marcelo. Manual da execução civil. 5. ed. rev. e atual. Rio de Janeiro: Forense, 2015.

ALMEIDA, Diogo Assumpção Rezende de Almeida. Das convenções processuais no processo civil. Tese de Doutorado, Faculdade de Direito. Rio de Janeiro: Universidade do Estado do Rio de Janeiro, 2014.

AMARAL, Guilherme Rizzo. As astreintes e o novo Código de Processo Civil. Revista de Processo, São Paulo: Revista dos Tribunais, v. 35, n. 182, p. 181-214, abr. 2010a.

AMARAL, Guilherme Rizzo. As astreintes e o processo civil brasileiro: multa do artigo 461 do CPC e outras. 2. ed. rev. atual. e ampl. Porto Alegre: Livraria do Advogado Editora, 2010b.

AMARAL, Guilherme Rizzo. Do cumprimento de sentença que reconheça a exigibilidade de obrigação de fazer, de não fazer ou de entregar coisa. In WAMBIER et al. (Coord.). Breves comentários ao novo Código de Processo Civil. São Paulo: Editora Revista dos Tribunais, 2015.

ARENHART, Sérgio Cruz. A doutrina brasileira da multa coercitiva - três questões ainda polêmicas. In MEDINA, José Miguel Garcia; CRUZ, Luana Pedrosa de Figueiredo; CERQUEIRA, Luis Otávio Sequeira; GOMES JUNIOR, Luiz Manoel (coord.). Os poderes do juiz e o controle das decisões judiciais - estudos em homenagem à Professora Teresa Arruda Alvim Wambier. São Paulo: Revista dos Tribunais, 2008.

ASSIS, Araken de. Comentários ao código de processo civil. Vol. XIII, 2. ed. São Paulo: Revista dos Tribunais, 2018.

ASSIS, Araken de. Processo Civil brasileiro - volume IV (livro eletrônico): Manual da Execução. São Paulo: Editora Revista dos Tribunais, 2016.

ATAÍDE Jr., Jaldemiro Rodrigues de. Negócios jurídicos materiais e processuais - Existência, validade e eficácia - Campo-invariável e campos-dependentes: sobre os limites dos negócios jurídicos processuais. Revista de Processo. v. 244, jun. 2015.

AVELINO, Murilo Teixeira. A posição do magistrado em face dos negócios jurídicos processuais - já uma releitura. In.: CABRAL, Antonio do Passo; NOGUEIRA, Pedro Henrique (coords). Coleção Grandes Temas do novo CPC. v. 1. ed. 2. Salvador: JusPodivm, 2016.

BOCALON, João Paulo. Os negócios jurídicos processuais no Novo Código de Processo Civil Brasileiro. Dissertação de Mestrado, Pontifícia Universidade Católica de São Paulo. São Paulo, 2016.

BORGES, Marcus Vinícius Motter. Medidas coercitivas atípicas nas execuções pecuniárias: parâmetros para a aplicação do art. 139, IV do CPC/15. São Paulo: Thomson Reuters, 2019.

CARNELUTTI, Francesco. Sistema de direito processual civil. São Paulo: Classic Book, 2000. 
CHABAS, François. Lastreinte em droit français. Doutrinas essenciais Obrigações e Contratos, v. 2, p. 11591164, jun. 2011.

CORDEIRO, Adriano Consentino. Negócios jurídicos processuais e as consequências do seu descumprimento. Tese de Doutorado. Curitiba: Universidade Federal do Paraná, 2016.

COSTA, Judith Martins. A boa-fé no direito privado: critérios para a sua aplicação. $2^{a}$ ed. São Paulo: Saraiva, 2018.

DIDIER Jr., Fredie; CABRAL, Antonio do Passo. Negócios jurídicos processuais atípicos e execução. Revista de Processo, v. 275, p. 193-228, jan. 2018.

DIDER Jr., Fredie; CUNHA, Leonardo Carneiro da; BRAGA, Paula Sarno; OLIVEIRA, Rafael Alexandria de. Curso de direito processual civil: execução. 7ª Ed. Salvador: Juspodivm, 2017.

DIDIER Jr., Fredie; NOGUEIRA, Pedro Henrique Pedrosa. Promessa de recompensa judicial. In ALVIM, Arruda (coord.) et al. Execução civil e temas afins - do CPC/1973 ao Novo CPC - estudos em homenagem ao professor Araken de Assis. São Paulo: RT, 2014.

DONIZETTI, Elpídio. Novo Código de Processo Civil comentado. 2. ed. rev., atual. e ampl. São Paulo: Atlas 2017.

DOUTOR, Maurício Pereira. Medidas executivas atípicas na execução por quantia certa: diretrizes e limites de aplicação. Dissertação de Mestrado. Curitiba: Universidade Federal do Paraná, 2019.

DURO, Cristiano. Execução e democracia. Salvador: Juspodivum, 2018.

FILHO, Ruy Alves Henriques. As cláusulas gerais no processo civil. Revista de Processo. v. 155, p. 335364, jan. 2008.

FONSECA E SILVA, Augusto Vinícius. Princípios pamprocessuais ou metaprocessuais. Salvador: Editora Juspodivm, 2019.

GAJARDONI, Fernando da Fonseca. Flexibilidade procedimental: um novo enfoque para o estudo do procedimento em matéria processual. Tese de Doutorado. São Paulo: Universidade de São Paulo, 2007.

GAJARDONI, Fernando da Fonseca; DELLORE, Luiz; ROQUE, André Vasconcellos; OLIVEIRA Jr., Zulmar Duarte de. Execução e recursos: comentários ao CPC de 2015, v. 3. 2. ed. Rio de Janeiro: Forense; São Paulo: Método, 2018.

GUERRA, Marcelo Lima. Execução indireta. São Paulo: Editora Revista dos Tribunais, 1998.

LUCCA, Rodrigo Ramina. Disponibilidade processual: a liberdade das partes no processo. São Paulo: Revista dos Tribunais, 2019.

MARINONI, Luiz Guilherme. Técnica processual e tutela dos direitos. 6. ed. rev. e atual. São Paulo: Thomson Reuters Brasil, 2019.

MARINONI, Luiz Guilherme. Tutela ressarcitória na forma específica. Revista de Processo, v. 300, fev. 2020.

MARZAGÃO, Newton Coca Bastos. A multa (astreintes) na tutela específica. Dissertação de mestrado, Faculdade de Direito. São Paulo: Universidade de São Paulo, 2013.

MAZZEI, Rodrigo Reis. Código civil de 2002 e o judiciário: apontamentos na aplicação das cláusulas gerais. In: DIDIER Jr. Fredie; MAZZEI, Rodrigo Reis. Reflexos do novo código civil no direito processual. Salvador: Juspodivm, 2006.

MEDINA, José Miguel Garcia. Execução: Teoria Geral, princípios fundamentais e procedimento no processo civil brasileiro. 5. ed. rev., ampl. e atual. São Paulo: Editora Revista dos Tribunais, 2017.

MELLO, Marcos Bernardes de. Teoria do fato jurídico: plano da existência, 11. ed. São Paulo: Saraiva, 2001. 
MINAMI, Marcos Youji. Da vedação ao non factibile: uma introdução às medidas executivas atípicas. Salvador: Juspodivm, 2019.

MOREIRA, José Carlos Barbosa. Temas de direito processual: segunda série. $2^{\mathrm{a}}$ ed. São Paulo: Saraiva, 1988.

NOGUEIRA, Pedro Henrique. Negócios jurídicos processuais. 3. ed. rev., ampl. e atual. Salvador: Editora JusPodivm, 2018a.

NOGUEIRA, Pedro Henrique. Gestão da execução por meio de negócios jurídicos processuais no processo civil brasileiro. Revista de Processo, v. 286, p. 325-342, dez. 2018 b.

NERY, Carmen Lígia Barreto de Andrade Fernandes. O negócio jurídico processual como fenômeno da experiência jurídica - Uma proposta de leitura constitucional adequada da autonomia privada em processo civil. Tese de Doutorado em Direito. São Paulo: Pontifícia Universidade Católica de São Paulo, 2016.

OLIVEIRA, Carlos Aberto Alvaro de. Do formalismo no processo civil: proposta de um formalismovalorativo. 4. ed. São Paulo: Saraiva, 2010.

PEREIRA, Rafael Caselli. A multa judicial (astreinte) e o CPC/2015. 2. ed. rev. e ampl. Porto Alegre: Editora Livraria do Advogado, 2018.

REALE, Ana Luísa Fioroni. A multa astreinte como importante medida de apoio, prevista no ordenamento jurídico brasileiro, diante do artigo 139, IV, do novo Código de Processo Civil. Dissertação de Doutorado em Direito. São Paulo: Pontifícia Universidade Católica de São Paulo, 2016.

REDONDO, Bruno Garcia. Negócios jurídicos processuais atípicos no Direito Processual Civil brasileiro: existência, validade e eficácia. Tese de Doutorado em Direito. São Paulo: Pontifícia Universidade Católica de São Paulo, 2019.

THEODORO Jr., Humberto. Curso de direito processual civil - vol. III. 50. ed. rev., atual. e ampl. Rio de Janeiro: Forense, 2017.

ZANETI Jr., Hermes. Comentários ao código de processo civil. Vol. XIV, 2. ed. São Paulo: Revista dos Tribunais, 2018.

ZAVASCKI, Teori. Comentários ao código de processo civil. Vol. XII, 2. ed. São Paulo: Revista dos Tribunais, 2018. 